\author{
Katarzyna KUBISZEWSKA, PhD \\ Faculty of Management and Economics, Gdansk University of Technology \\ e-mail: katarzyna.kubiszewska@zie.pg.gda.pl
}

DOI: $10.15290 /$ ose.2017.05.89.17

\title{
TRANSFORMATION OF THE BANKING SECTOR AS AN ELEMENT OF ECONOMIC TRANSFORMATION IN SOUTH-EAST EUROPE
}

\begin{abstract}
Summary
The issue of stability in economy is essential, both in theoretical as well as in practical discussion. It is especially important in an environment of economic transformation. The aim of the article is to assess the economic stability during the transformation of the south-east region of Europe over a period of 19 years (1995-2014), and the mutual relation between the economic stability and the transformation process, including the transformation of banking sectors. The countries selected to the research were Albania, Bosnia and Hercegovina, Bulgaria, Croatia, Romania and Serbia.

The study shows the strong correlation between transformation process of economy and banking sectors and not more than moderate relationship between transformation and stability, in some of the studied countries. The methods used include a literature review of the theory on the transformation process with special focus on the Balkan region, as well as a comparative analysis of data, which addresses the progress of the economic and banking sector's transformation and measures the macroeconomic stability in this region and Pearson correlation for assessing mutual impacts of the variables.
\end{abstract}

Key words: economic transformation, banking sector, South-East Europe

JEL Classification: E020, E440, G00

\section{Introduction}

The transformation process is essential for all economic systems as a whole, as well as for each sector within these systems. The progress of the process does not have to be equally smooth from a macroeconomic perspective as well as in a form a business sector's (e.g. banking sector's) perspective. The transformation processes in both cases are influenced by various factors. Special importance is applied to the banking sector, which constitutes mainly the financial sphere of the countries undergoing transformation.

The aim of the article is to check how the transformation process has been developed in the region of the south-east Europe where, in many cases, a need to build independence and statehood from scratch has occurred, both in the general economy as well as in the case of the banking sectors, and how the transformation process is connected with macroeconomic stability. The methods used include a literature review of the theory on 
the transformation process, with special focus on the Balkan region, as well as a comparative analysis of data, which addresses the progress of the economic and banking sector's transformation and measures the macroeconomic stability in this region. The time period of the research covers 19 years, from 1995 to 2014.

\section{Economic and banking transformation in theory}

The literature does not clearly define the concept of transformation. The term transformation comes from Latin and it means conversion [Transformacja systemowa w Polsce..., 1993, p.8].

The doctrine of transformation distinguishes two strands of the issues. In a broad sense, it refers to the transformation of civilization and not only to the economic system; this means that the economy as a whole will be rebuilt, and not only the economic system [Chołaj, 1998, p. 342]. In the narrower meaning, on the other hand, transformation can be understood as changing one economic system to another economic system.

The literature provides two dimensions for transformation. The term political transformation should be understood as a change of political regime involving the introduction of a system of political democracy along with a wide range of constitutional freedoms and liberties, for example, freedom of association and freedom of trade unions. On the other hand, the economic dimension of transformation includes measures to create entities that operate in market conditions and that accomplish their objectives in the spirit of freedom and respect for individual rights [Bałtowski, Miszewski, 2006, p. 24].

Some authors [Bromley, 1993, p. 131-151] identify transformation with the infrastructure of a system that is characteristic of a market. This means that transformation is the transition from a centrally planned economy to a market economy, including changing the political system and creating conditions for the functioning of all market operators, i.e. enterprises, budgetary units, and households.

Another group of authors [Wojtyna, 1997 p. 9; Rosati, 1998] emphasizes the transformation process with the process of changes. For these authors, it means changing the current system from a centrally planned economy of a socialist type to a market economy that is similar to the capitalist system. It is a process involving many areas of economy including social and political ones [Bożyk, 2002]. Kołodko is consistent with this opinion, and expands the definition of transformation to include features characteristic of both the centrally planned economy and the market economy. In his view, postsocialist political transformation is a process of gradual transition from a centrally planned socialist economy, which is based on the dominance of state-owned means of production, and bureaucratic regulations, to a capitalist free market economy based on the domination of privately owned property and liberal deregulation [Kolodko, 2001, p. 25].

Gomulka [1998, p. 163-171] defined transformation as a period during which existing economic solutions are quickly removed, but the effects of the changes, in the form of the productivity increase and development, have not yet appeared. In all economies in transition, governments faced the serious task of solving the problems of macroeconomics and recovering the stability within the new system.

Economic transformation involves a series of measures: 
- the deregulation of prices, which will then be governed by supply and demand,

- changes in the economy's ownership structure through the privatization of stateowned enterprises,

- an increase in economic freedoms by changing the way the economy is regulated (i.e. elimination of bureaucracy) and enabling natural and legal persons to participate in the market,

- $\quad$ access to foreign capital and investment in the local market,

- $\quad$ starting of the capital market, where shares of listed companies are traded.

The scope of activities needed to be carried out during an overall economic transformation is consistent with that which is necessary in the case of the banking sector.

Establishing a banking system based on a market approach is usually part of the overall process of reforming programs. The aim of the reforms is to build a healthy banking system that meets the tasks required in a well-performing market economy. These tasks are, the improvement of risk management, resource allocation and the exercising of corporate control, the mobilization of savings, support for the exchange of goods and services, and the elimination of shocks in the financial and the real sphere of the economy [Levine, 1997, pp. 690-712; ECB, 2010].

Reconstruction of the banking system is a key element of transformation because efficient commercial banks are a prerequisite for conducting market competition, which in turn is a condition of privatization.

The literature distinguishes two approaches to transforming the banking sector; these are the new entry and rehabilitation processes. The first one concentrates on the spontaneous break-up and privatization of state banks, a (de-facto) policy of liberal entry of new banks, and sometimes the liquidation of old banks; while the other is focused on the recapitalization and institutional development of existing state banks, some limited breakups, limited privatization, and more of limited entry. The choice between the approaches is determined by the initial conditions of the banking market, macroeconomic developments, and other reforms that have taken place since the beginning of the transition, which is related to the institutional legacy and macroeconomic developments. Other factors influencing banking reforms are legal and enterprise reforms [Claessens, 1996, p. 3].

Creating a two-tier banking sector involves three main areas, i.e. the privatization of financial institutions and market consolidation, the creation of institutions that support a market economy, and the introduction of a legal base in order to guarantee a stable market and to monitor the sector. The process of transforming the banking sector requires a number of steps. The first is the privatization of state-owned banks; this means the sale of state-owned assets to private investors, both domestic and foreign. Another element is deregulation, which allows foreign banks to operate in the local market. The third necessary measure is to recapitalize the banks, which is always costly for the budget. The collapse of an economy deprives the banks of most of their resources, therefore, it is impossible to avoid major losses in the banking sector. The savings are small, there are inadequate capital resources, and their ratio to total assets is unfavorable. 


\section{Transformation and stability in the literature}

Macroeconomic stability can be used with reference to the business cycle to determine the frequency and other morphological characteristics of fluctuations. It should be then understood as a set of phenomena that includes at least three dimensions: financial market stability, monetary stability, and business cycles. Simultaneously, stability can refer to the financial area in which case it will be associated with the financial system's resilience to any kinds of shock, including fluctuations in the economy. The fundamental difference between both approaches is the identification of the determinant of change. In the first case it is the business cycle, while in the second it is the endogenous changes taking place in the financial sector.

Although the issue of macroeconomic stability is commonly understood as a situation where the economy reduces its vulnerability to the impact of external shocks, there is no single unique definition of the term. Taking the definition of a banking stability as the example, the existing explanations found in the literature can be split into three categories. First, it is associated with the quality of the sector, meaning the accomplishment of the sector, its tasks, and its sound performance [Lindgren, 1997; Iwanicz-Drozdowska, 2002]. Second, stability can refer to sound interdependence of business sectors and their interaction [Lindgren, 1997; Fisher, 1997; Trichet, 2000; Kaufman, Scott, 2001]. The third group of definitions relies on a lack of crisis [Allen, Gale, 2004; IwaniczDrozdowska, 2002].

A stable economy provides a framework for an improved economic performance which desires stable low inflation, low long-term interest rates, low public debt or/and low general government deficits (relative to GDP). The stable low inflation encourages higher investments which improve productivity as well as price and non-price competitiveness. The maintenance of steady growth and price stability helps to keep short term and long term interest rates low, which determine the debt-servicing costs. A lower public debt to GDP ratio signifies that a state has the leeway to spend more, especially needed in times of crisis. Another important aspect of macroeconomic stability is the low deficits, proving that a government is in a better position to recover in a case of economic externalities and shocks. Macroeconomic stability support to anchor stable expectations and this can act as an incentive for an economy to attract inflows of foreign direct investment and it increases higher levels of consumer and business confidence.

Since there is no common definition for the transformation process nor for economic stability, the literature lists two excluding relations between reforms (which are the elements of transformation) and the market's performance (as a consequence of the stability) [Brissimis et. al., 2008, p. 5] One of the approaches points out a conflict between process of reforms in form of deregulation and symptoms of market's performance, e.g., bank risk-taking and competition [Matutes, Vives, 2000, pp. 1-34; Bolt, Tieman, 2004, pp. 783-804; Allen, Gale, 2004, pp. 453-480]. In addition, the researchers found a negative correlation between deregulation and the banking market's performance. In their opinion, the liberalization of this market (which is one of the indications of a market economy) fuels a decline in productive efficiency and/or a total factor productivity growth [Grifell-Tatjé, Lovell, 1996, pp. 1281-1303; Wheelock, Wilson, 1999, pp. 213-234]. 
The other group of studies researched whether deregulation has a direct impact on the banks' performance. They concluded that deregulation boosts efficiency through operational savings, thus leading to a surge in productivity growth [Kumbhakar et. al., 2001; Isik, Hassan, 2003, pp. 1455-1485].

\section{Research methods}

The researches were conducted in countries from the region of south-east Europe, namely Albania, Bosnia and Hercegovina, Bulgaria, Croatia, Macedonia, Romania, and Serbia. All of these countries decided to transform their economies from a centrally planned system and rebuild their economic system to form a market-based one. They are at different stages of the process; three are already European Union Member States, while the others are candidates or potential candidates.

The study covers the period between 1995 and 2014 and was divided into the following steps. First, a comparative analysis of the engagement of the general economic transformation with the banking sectors' transformation was carried out. In order to conduct this part of research, the EBRD (European Bank for Research and Development) indices were employed to measure the economic transformation stage. The scale of the transition indicator ranges from 1 to 4.3, where 1 represents little or no change from a rigid centrally planned economy, and 4.3 represents the standards of a market economy. The indicator scores reflect the EBRD's judgment about the progress in transition for specific countries. The scores are based on the classification system, which was originally developed in the 1994 Transition Report, but have been refined and amended in subsequent reports. In order to carry out the multi-country analysis the size of the hexagons were calculated, the vertexes of which were determined by the individual transformation indicators: large and small scale privatization (LSP, SSP), governance and enterprise restructuring (GER), price liberalization (PL), trade and forex system (TFS), and competition policy (CP). The formula (1) for the size of the hexagon is based on Pythagorean theorem and employs Heron's formula (the size of the base of pyramid, which apex is the center of Euclidean space):

$$
\begin{aligned}
{[(\mathrm{LSP} \times \mathrm{SSP})+} & (\mathrm{SSP} \times \mathrm{GER})+(\text { GER } \times \mathrm{PL})+(\mathrm{PL} \times \mathrm{TFS})+ \\
& (\text { TFS } \times \text { CP })+(\mathrm{CP} \times \mathrm{LSP})] \times \mathrm{k} .
\end{aligned}
$$

where $\mathrm{k}=1 / 2 \sin 60^{\circ}$

It was decided that the biggest possible size achievable was 48,038, which represents the state expected after the transformation had been completed.

In order to evaluate the process of banking transformation, the Banking Transformation Triangle [Fries, Taci, 2002, p. 4] was used. Each of triangle's vertexes represents a variable referring to the development of the banking sector: the EBRD banking reform index, the EBRD entities reform index, and the private sector's share of assets in the banking sector. Similarly, for the hexagon for general economy transformation, the highest possible achievable value is 4.3. Since an equilateral triangle represents the uniformity of reforms' process, the highest private sector's share of assets in the banking 
sector $(100 \%)$ corresponds to a value of 4.3. Lower private engagement is represented by a respectively lower value.

Macroeconomic stability was measured using the Macroeconomic Stability Pentagon, introduced by Mundel and Phillips and popularized in Poland by Kołodko [1993]. This is a regular pentagon, the vertexes of which indicate each of the main macroeconomic indicators: GDP - economic growth as measured using the GDP's annual growth rate; $\mathrm{CA}$ - current accounts in relation to the GDP; GG - the gross government deficit to GDP ratio; CPI - inflation rate; and $\mathrm{U}$ - unemployment rate. The application of the respective indicators is not coincidental because the bigger the size of pentagon the more stable the macroeconomic situation is. The size of pentagon is calculated using Pythagorean theorem and Heron's formula and is presented with formula (2),

$$
[(\Delta \mathrm{GDP} \times \mathrm{U})+(\mathrm{U} \times \mathrm{CPI})+(\mathrm{CPI} \times \mathrm{G})+(\mathrm{G} \times \mathrm{CA})+(\mathrm{CA} \times \Delta \mathrm{GDP})] \mathrm{x} \mathrm{k},
$$

where: $\mathrm{k}=1 / 2 \sin 72^{\circ}$

Its size equals to the sum of five triangles and cannot exceed 1, which represents the ideal situation and is, unfortunately, unachievable.

Eventually, it was checked what is the correlation between three variables: economic transformation, macroeconomic stability and banking sectors' transformation. In order to choose the methods for statistical comparison, the distribution of the variables was analyzed with normal distribution using the Kolmogorov-Smirnov test. To evaluate the strength and direction of the relationships between quantitative variables the correlation coefficient r-Pearson and rho-Spearman was used. Throughout the study, for the purpose of this calculation, the statistical significance was $\mathrm{p}<0.05$.

\section{Research results}

The development of the economic transformation is measured using the EBRD Transformation Index. A comparison of the achievements attained within two decades shows significant progress (Figure 1.). In 1995, the situation concerning the engagement in the transformation process was very differential. The worst situation was noted in Bosnia and Hercegovina, where only in the area of small-scale privatization was anything done. The other indicators achieved 1.0, representing little or no change compared to the initial stage - i.e. the centrally planned economy. On the other hand, the country most engaged in the transformation process was Croatia, where indices in small-scale privatization, price liberalization, and the trade and forex system were scored at 4.0. The worst index for this country was recorded in competition policy. Consequently, the sizes of the hexagons built on the indicators varied. The difference in size between Bosnia and Croatia in 1995 was greater than a factor of seven. The other country with low achievement was Serbia, whose hexagon's size did not exceed 5.8 units, while other countries' hexagons were nearing 20 units. 


\section{EBRD Transformation Index (EBRD)}

FIGURE 1.

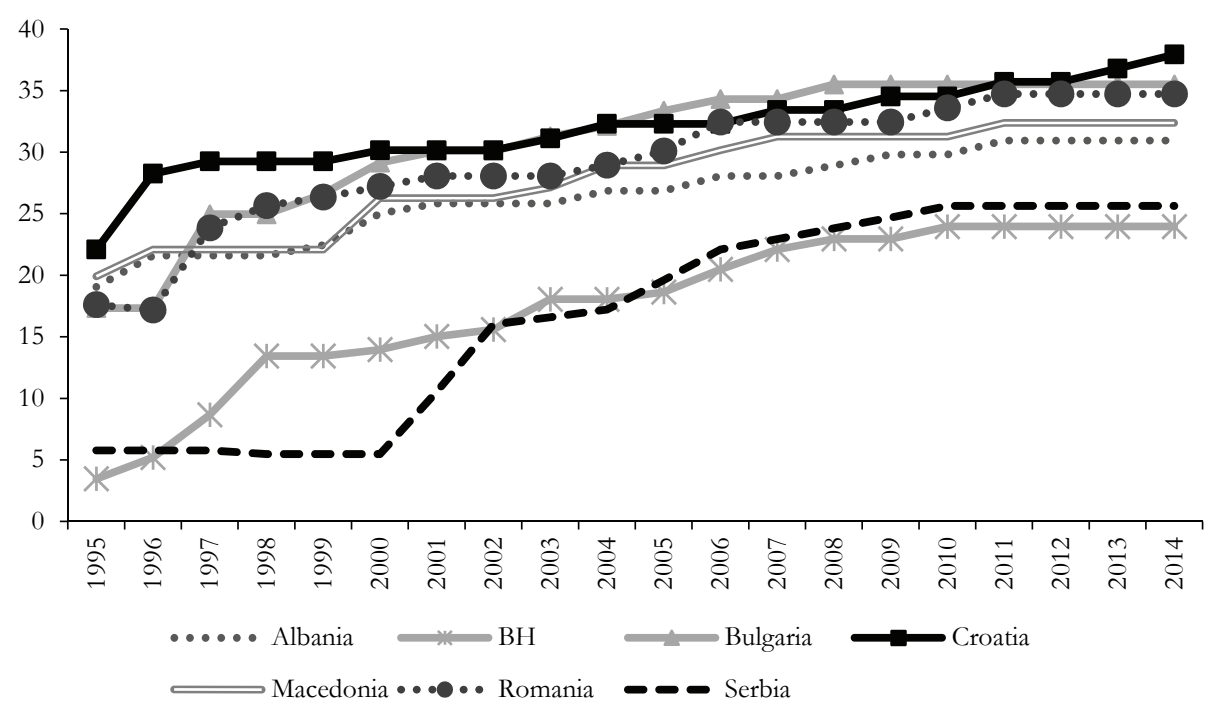

Reference: own compilation, based on [EBRD Transition Reports 1995-2014].

The progress achieved in the region as the whole is noticeable (Table 1). The sizes of the hexagons for 2014 for all countries, were much more similar. Still, Bosnia recorded the smallest sized hexagon, while Croatia recorded the biggest; but now the difference was only $60 \%$, not over $700 \%$ as it was in 1995 . Simultaneously, Bosnia achieved the strongest progress, measured both in relative and absolute values, with the second highest coefficient of variation.

TABLE 1. Indicators for statistical dispersion - EBRD Transformation Index hexagons for the years 1995-2014

\begin{tabular}{|c|c|c|c|c|c|c|c|}
\hline & Albania & BH & Bulgaria & Croatia & Macedonia & Romania & Serbia \\
\hline Min. & 19.06 & 3.46 & 17.33 & 22.08 & 19.92 & 17.18 & 5.48 \\
Max. & 30.95 & 23.95 & 35.50 & 37.93 & 32.37 & 34.74 & 25.64 \\
The average annual & 1.04 & 1.12 & 1.04 & 1.03 & 1.03 & 1.04 & 1.09 \\
rate of change & & & & & & & \\
Absolut difference & 11.89 & 20.49 & 18.17 & 15.84 & 12.45 & 17.55 & 20.16 \\
$\begin{array}{c}\text { Relative difference } \\
\text { Coefficient of } \\
\text { variation }\end{array}$ & 1.624 & 6.914 & 2.048 & 1.717 & 1.625 & 1.972 & 4.439 \\
& & 5.74 & 5.60 & 3.50 & 4.12 & 5.04 & 7.75 \\
\hline
\end{tabular}

Reference: own compilation, based on [EBRD Transition Reports 1995-2014]. 


\section{Banking sector transformation - Triangle Banking Reform (TBR)}

Since the banking sector is an element of the general economy, the situation concerning the transformation process in this sector cannot vary greatly from the general economy's transformation (Figure 2.).

\section{Triangle Banking Reform (TBR)}

FIGURE 2.

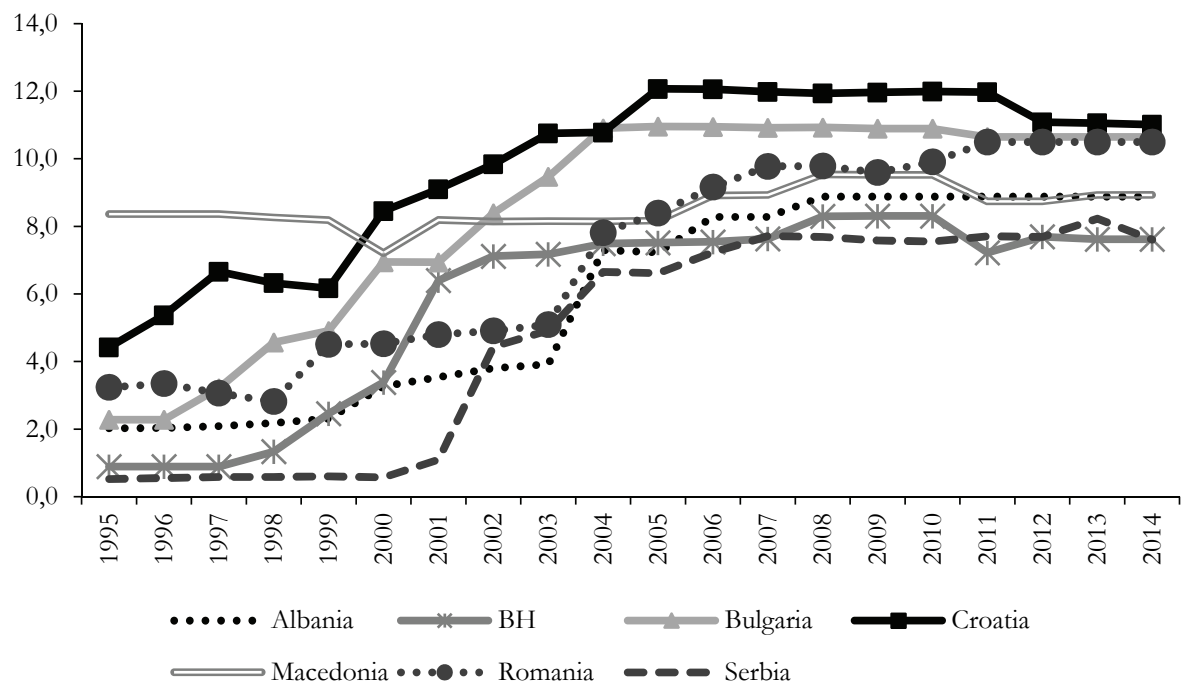

Reference: own compilation, based on [EBRD Transition Reports 1995-2014].

The poorest situation in 1995 was recorded in Serbia, the main features of which were the minimal progress of banking and entities' reform, as well as a relatively low share of private investors in the banking sector compared to other countries in the study. The best situation, relatively, was in Macedonia, which achieved its score thanks to a 100\% share of the banking sector being held by private investors. This share remained closed to $100 \%$ throughout the whole period of the study. The difference in triangle sizes was close to a factor of 16. The strongest progress was achieved by Serbia, both in relative values as well as the average annual rate of increase, which was the highest; however, its score did not vary greatly from the other countries' scores in 2014 (Table 2.). 
TABLE 2. Indicators of statistical dispersion - Banking Reform Triangles for the years 1995-2014

\begin{tabular}{|c|c|c|c|c|c|c|c|}
\hline & Albania & BH & Bulgaria & Croatia & Macedonia & Romania & Serbia \\
\hline Min. & 2.03 & 0.89 & 2.28 & 5.37 & 7.21 & 2.82 & 0.56 \\
Max. & 8.88 & 8.30 & 10.95 & 12.07 & 9.54 & 10.50 & 8.23 \\
The average annual & 1.09 & 1.14 & 1.09 & 1.05 & 1.00 & 1.07 & 1.23 \\
rate of change & & & & & & & \\
Absolute difference & 6.85 & 7.41 & 8.68 & 6.70 & 2.33 & 7.68 & 7.67 \\
Relative difference & 4.38 & 8.54 & 4.67 & 2.49 & 1.07 & 3.24 & 14.64 \\
Coefficient of & 0.49 & 0.43 & 0.33 & 0.22 & 0.07 & 0.39 & 0.61 \\
variation & & & & & & & \\
\hline
\end{tabular}

Reference: own compilation, based on [EBRD Transition Reports 1995-2014].

\section{Macroeconomic Stability Pentagon (MSP)}

In 1995, macroeconomic stability was poorest in Serbia, whose size of pentagon was over seven times smaller than the biggest pentagon for Croatia (Figure 3.).

\section{Macroeconomic Stability Pentagon (MSP)}

FIGURE 3.

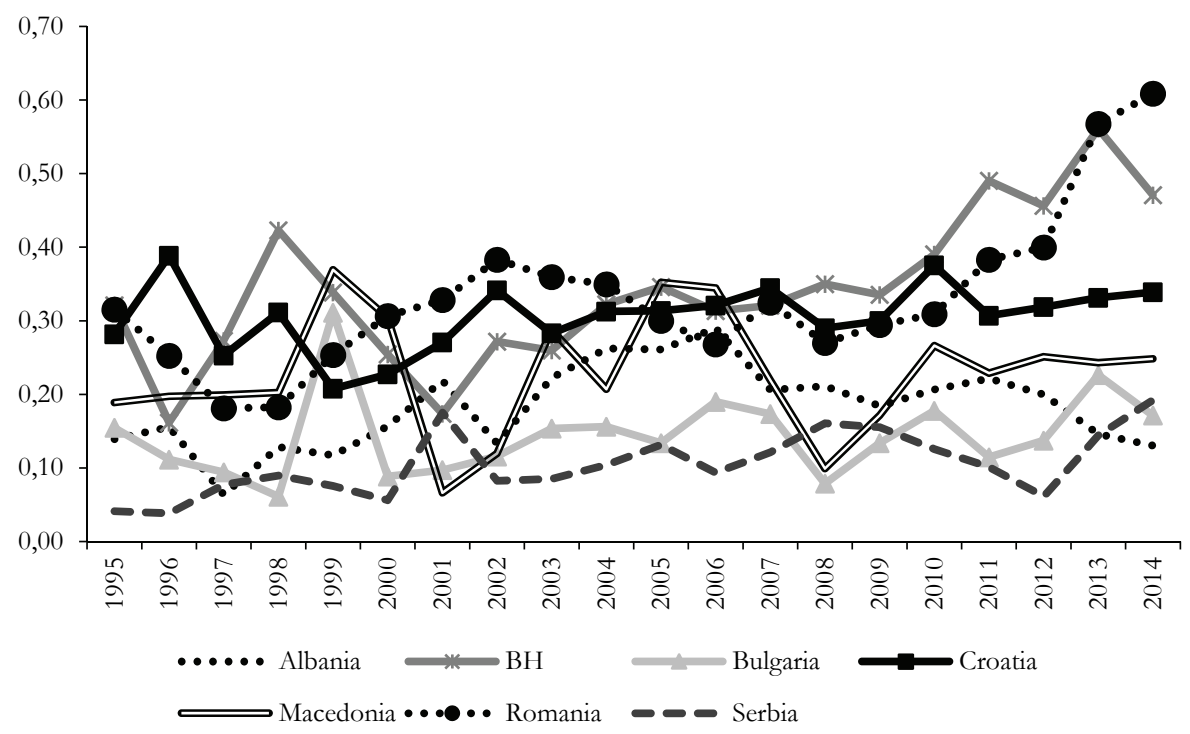

Reference: own compilation, based on [EBRD Transition Reports 1995-2014]. 
Generally speaking the worst situation concerning macroeconomic stability in the countries studied was recorded at the end of the nineties, apart from Bulgaria, which only faced the decrease in general stability in 2001. All of the countries studied experienced their worst situation in 2008 what is associated with consequence of the global economic crisis. Both the literature [Bartlett, Monastiriotis, 2010, pp. 477-504; Sen, Atlay, 2012] as well as the analysis of macroeconomic situation prove that the GDP reduction, followed by the unemployment rate hoist, the increase of the general government imbalance and the higher current account deficits, have got their roots in the global economic situation.

The strongest improvement was recorded in Serbia, whose MSP increased by over 6 units, achieving the second the best average annual rate of change (Table 3.). Only in Albania was the situation worse in 2014 than in 1995. The other countries' pentagons increased from 25\% in Bulgaria to almost $90 \%$ in the case of Romania.

TABLE 3.

Indicators of statistical dispersion - Macroeconomic Stability Pentagons for the years 1995 - 2014

\begin{tabular}{|c|c|c|c|c|c|c|c|}
\hline & Albania & BH & Bulgaria & Croatia & Macedonia & Romania & Serbia \\
\hline Min. & 0.06 & 0.16 & 0.06 & 0.21 & 0.07 & 0.18 & 0.04 \\
Max. & 0.29 & 0.56 & 0.31 & 0.47 & 0.37 & 0.61 & 0.26 \\
The average annual & 1.35 & 1.06 & 1.21 & 1.01 & 1.17 & 1.05 & 1.17 \\
rate of change & -0.01 & 0.15 & 0.02 & 0.06 & 0.06 & 0.29 & 0.15 \\
Absolute difference & 0.97 & 1.70 & 1.23 & 1.66 & 1.52 & 1.89 & 6.20 \\
$\begin{array}{c}\text { Relative difference } \\
\text { Coefficient of } \\
\text { variation }\end{array}$ & 0.04 & 0.10 & 0.05 & 0.06 & 0.07 & 0.12 & 0.05 \\
\hline
\end{tabular}

Reference: own compilation, based on: [EBRD Transition Reports 1995-2014].

Further analysis is focused on finding a correlation between the Triangle Banking Reform, EBRD Transformation Index and the Pentagon Macroeconomic Stabilization. In order to choose the appropriate statistical tests, the variables were checked to see if they did not differ significantly from the normal distribution. The results are presented in Table 4.

In most cases, the statistical tests that were performed (Kolmogorov-Smirnov test) did not show that the distributions of the Triangle Banking Reform, the Indicator transformation for the EBRD, and the Macroeconomic Stability Pentagon, for the years 1995-2014 differed significantly from the normal distribution. Therefore, in order to investigate the relationship between these variables, we determined the correlation coefficient, $r$ Pearson, and examined the relevance of the parametric tests. the results are presented in Table 5. 
TABLE 4.

Kolmogorov-Smirnov test

\begin{tabular}{|c|c|c|c|c|}
\hline & Variable & TBR & EBRD & MSP \\
\hline \multirow{2}{*}{ Albania } & $\mathrm{KS}$ & 0.235 & 0.122 & 0.125 \\
\cline { 2 - 5 } & value p & 0.185 & 0.892 & 0.873 \\
\hline \multirow{2}{*}{$\mathrm{BH}$} & $\mathrm{KS}$ & 0.328 & 0.16 & 0.126 \\
\cline { 2 - 5 } & value p & $0.02^{*}$ & 0.625 & 0.872 \\
\hline \multirow{2}{*}{ Bulgaria } & $\mathrm{KS}$ & 0.306 & 0.205 & 0.167 \\
\cline { 2 - 5 } & value p & $0.037 *$ & 0.324 & 0.574 \\
\hline \multirow{2}{*}{ Croatia } & $\mathrm{KS}$ & 0.251 & 0.129 & 0.111 \\
\cline { 2 - 5 } & value p & 0.134 & 0.849 & 0.943 \\
\hline \multirow{2}{*}{ Macedonia } & $\mathrm{KS}$ & 0.186 & 0.19 & 0.123 \\
\cline { 2 - 5 } & value p & 0.439 & 0.412 & 0.937 \\
\hline \multirow{2}{*}{ Romania } & $\mathrm{KS}$ & 0.201 & 0.184 & 0.165 \\
\cline { 2 - 5 } & value p & 0.344 & 0.452 & 0.589 \\
\hline \multirow{2}{*}{ Serbia } & $\mathrm{KS}$ & 0.26 & 0.203 & 0.115 \\
\cline { 2 - 5 } & value p & 0.111 & 0.336 & 0.927 \\
\hline
\end{tabular}

Reference: own compilation

Only in the case of Macroeconomic Stability Pentagon and the EBRD Transformation Index in Bosnia and Hercegovina and in Bulgaria, did it turn out that these variables differ significantly from the normal distribution. Therefore, the correlation between the variables of the other two indicators was examined using nonparametric tests by determining the correlation coefficient, rho-Spearman, the results of which are presented in Table 5.

TABLE 5.

\section{Correlation tests}

\begin{tabular}{|c|c|c|c|c|c|c|c|}
\hline \multicolumn{2}{|c|}{} & \multicolumn{2}{c|}{$\mathrm{r} /$ rho } & \multicolumn{2}{c|}{ test T } & \multicolumn{2}{c|}{ value $\mathrm{p}$} \\
\cline { 3 - 9 } \multicolumn{2}{c|}{ Albania } & TBR & EBRD & TBR & EBRD & TBR & EBRD \\
\cline { 2 - 8 } & MSP & 0.935 & & 11.154 & & $<0.001^{*}$ & \\
\hline \multirow{2}{*}{ BH } & EBRD & 0.544 & 0.465 & 2.749 & 2.227 & $0.013^{*}$ & $0.039^{*}$ \\
\cline { 2 - 8 } & MSP & 0.348 & 0.181 & 1.574 & 0.782 & 0.133 & 0.445 \\
\hline \multirow{2}{*}{ Bulgaria } & EBRD & 0.754 & & 4.876 & & $<0.001^{*}$ & \\
\cline { 2 - 9 } & MSP & 0.359 & 0.522 & 1.633 & 2.594 & 0.12 & $0.018^{*}$ \\
\hline \multirow{2}{*}{ Croatia } & EBRD & 0.822 & & 6.128 & & $<0.001^{*}$ & \\
\cline { 2 - 9 } & MSP & 0.328 & 0.348 & 1.471 & 1.575 & 0.159 & 0.133 \\
\hline \multirow{2}{*}{ Macedonia } & EBRD & 0.59 & & 3.099 & & $0.006^{*}$ & \\
\cline { 2 - 9 } & MSP & -0.199 & 0.057 & -0.861 & 0.242 & 0.4 & 0.811 \\
\hline \multirow{2}{*}{ Romania } & EBRD & 0.893 & & 8.398 & & $<0.001^{*}$ & \\
\cline { 2 - 8 } & MSP & 0.555 & 0.521 & 2.834 & 2.588 & $0.011^{*}$ & $0.019^{*}$ \\
\hline \multirow{2}{*}{ Serbia } & EBRD & 0.983 & & 22.49 & & $<0.001^{*}$ & \\
\cline { 2 - 8 } & MSP & 0.541 & 0.587 & 2.731 & 3.079 & $0.014^{*}$ & $0.006^{*}$ \\
\hline
\end{tabular}

Reference: own compilation 
The statistical correlation coefficient $(p<0.05)$ tests confirm, that in some cases, a statistically significant correlation was recorded between all the indicators in the study, but in other cases, such a correlation was not observed.

Based on the value and sign of the correlation coefficient, we can conclude that in four countries, i.e. in Albania, Bulgaria, Romania and Serbia, there was a statistically significant correlation noted between the EBRD and the MSP, and the strength of the relationship between these two indicators was moderate. This means that with an increase in the ratio of transformation EBRD, the Pentagon Macroeconomic Stability index also grew. In the other three countries surveyed, the rate of transition EBRD showed no statistically significant correlation with the Pentagon Macroeconomic Stability index, which means that the rate of transformation of the EBRD does not significantly affect the rate of the Pentagon Macroeconomic Stability.

In almost all countries, the correlation between the Triangle Banking Reform and the EBRD Transformation Index was at least high. A very high strength of relationship between these two indicators was recorded in Bosnia and Herzegovina and Romania. Only in Macedonia, was it moderate.

When it comes to the relationship between the Triangle Reform Banking and the Pentagon for Macroeconomic Stabilization in Albania, Romania, and Serbia, it was only moderate during the period studied, and in the other countries surveyed such a relationship was not recorded, which means that the process of reforming the banking sector does not affect the macroeconomic situation there.

\section{Conclusions}

The transformation process is a crucial issue in the modern economy, especially in a turbulent environment. Therefore the macroeconomic stability belongs to one the key importance and shall be assessed with various methods. The economic stability, as well as the transformation process engagement, were evaluated with the sizes of polygons which vertices were pointed by various ratios and indices. In case of macroeconomic stability, these were five economic ratios while in case of transformation process they were the indices granted by EBRD, depending on the progress made by the countries in selected areas.

The study proved that over the studied period, the economic stability improved in most of the studied countries. Only in Albania, the situation worsens in 2014 comparing to 1995. Moreover, a strong dispersion of economic and banking sector's transformation processes in 1995 were combined with the noticeable progress within the studied period, mainly achieved by the underdeveloped economies, for example, Serbia.

Simultaneously, the study presented that relationship between the general situation in the economy and its transformation including banking sectors' transformation does not impact mutually. In Albania, Romania, and Serbia the correlations between the macroeconomic stability and economic transformation as well as between macroeconomic stability and banking sectors' transformation were not higher than moderate ( $\mathrm{r}$ ranges between $0,456$ and 0,587$)$. In Bulgaria, a moderate relationship ( $\mathrm{r}=0,522)$ was only detected between the EBRD and the MSP, while the other tests that were performed did not prove a significant correlation between transition and economic stability. The factors of 
macroeconomic stability in developing countries shall not be search only in the transformation process itself as well as the transformation process is not conditioned by the macroeconomic situation.

The other situation was examined is the case of correlation between the transformation process of the economy and of banking sectors. In almost all countries, this relation was at least high ( $\mathrm{r}=0,754$ in Bulgaria). A very high strength of it was recorded in Albania and Serbia (respectively $r=0,935$ and $r=0,983)$. Only in Macedonia $(r=0,59)$, it was only moderate. It confirms that the engagement of transformation process in a selected economic sector is the consequence of the general process taking place in the economy and both processes cannot exist without each other.

The further studies shall be focused on assessing the impact of transformation process on economy's and a banking sector's performance in conditions of transformation. It shall be also analyzed what determinants affect both macroeconomic and banking sector's performance and whether it is possible to talk about stability during economic transformation.

\section{References}

Allen F., Gale D., 2004, Competition and financial stability, "Journal of Money, Credit, and Banking", No. 36.

Bałtowski M., Miszewski M., 2006, Transformacja gospodarcza w Polsce, Wydawnictwo Naukowe PWN, Warszawa.

Barell R., Holand D., 2000, Foreign Direct Investment and Enterprise Restructuring in Central Europe, "Economics of Transition", 8 (2).

Bolt W., Tieman A.F., 2004, Banking competition, risk and regulation, "Scandinavian Journal of Economics", No. 106.

Bożyk P., 2002, 24 kraje Europy Środkowej $i$ Wschodnie, Oficyna Wydawnicza Szkoły Głównej Handlowej, Warszawa.

Brissimis S.N., Delis M.D., Papanikolaou N.I., 2008, Exploring the nexus between banking sector reform and performance: evidence from newly acceded EU countries, Working Pape, No. 73, https://doi.org/10.1016/j.jbankfin.2008.07.002_

Bromley D.W., 1993, Reconstituing Economic Systems: Institutions in national Development, "Development Policy Rewiev", No. 2, https://doi.org/10.1111/j.1467-7679.1993. tb00033.x.

Chołaj H., 1998, Transformacja systemowa w Polsce: szkice teoretyczne, Wydaw. Uniwersytetu Marii Curie-Skłodowskiej, Lublin.

Claessens S., 1996, Banking Reform in Transition Countries, The World Bank, Policy Research Working Paper, No. 1642.

EBRD Transition Reports 1995-2014, http://www.ebrd.com/transition-report (access: ...).

Fisher S., 1997, Banking soundness and the role of the Fund, [in:] Banking soundness and Monetary Policy, International Monetary Fund. 
Fries S., Taci A., 2005, Cost efficiency of banks in transition: Evidence from 289 banks in 15 postcommunist countries, "Journal of Banking and Finance", No. 29 (1), https:/ / doi.org/ 10.1016/j.jbankfin.2004.06.016_

Fries S., Taci A., 2002, Banking Reform and Development in Transition Economies, EBRD, Working Paper, No. 72.

Gomulka S., 1998, The Polish model of transformation and growth, "Economic of Transition", Vol. 6, Issue 1, DOI: 10.1111/j.1468-0351.1998.tb00042.x.

Grifell-Tatje E., Lovell C.A.K. 1996. Deregulation and productivity decline: the case of Spanish savings banks, "European Economic Review", No. 40, https://doi.org/10.1016/ 0014-2921(95)00024-0.

Isik I., Hassan M.K. 2003. Financial deregulation and total factor productivity change: an empirical study of Turkish commercial banks, "Journal of Banking and Finance", No. 27, https://doi.org/10.1016/s0378-4266(02)00288-1.

Iwanicz-Drozdowska M., 2002, Kryzysy bankowe: przyczyny i rozwiazania, Polskie Wydawnictwo Ekonomiczne, Warszawa

Kaufaman G.G., Scott K., 2001, Does Bank Regulation retard or contribute to Systemic Risk?, Center For Research On Economic Development And Policy Reform, Working Paper, No. 86, https://doi.org/10.2139/ssrn.257927.

Kołodko G., 1993, Kwadratura Koła, Warszawa.

Kolodko G., 2001, Globalization and Transformation Illusions and Reality, Paper presented to the Plenary Session of the VIIth Congress of Polish Economists Warsaw, January 25-26.

Kumbhakar S.C., Lozano-Vivas A., Lovell C.A.K., Hasan I., 2001, The effects of deregulation on the performance of financial institutions: the case of Spanish savings banks, "Journal of Money, Credit, and Banking", No. 33, https:/ / doi.org/10.2307/2673874.

Levine R., 1997, Financial Development and Economic Growth: Views and Agenda, "Journal of Economic Literature”, Vol. 35, No. 2, https:/ / doi.org/10.1596/1813-9450-1678.

Lingren C.J., 1997, How to keep the banking system sound in a period of change, [in:] Banking Soundness and Monetary Policy, International Monetary Fund.

Transformacja systemowa w Polsce: wybrane problemy, 1993, Z. Blok (red.), Wydawnictwo Adam Marszałek, Poznań.

Matutes C., Vives X., 2000, Imperfect competition, risk taking, and regulation in banking, "European Economic Review", No. 44, https://doi.org/10.1016/s0014-2921(98) 00057-9.

Rosati D., 1998, Polska droga do rynku, Polskie Wydawnictwo Ekonomiczne, Warszawa.

Sen A., Atlay H., 2012, The Channels of Contagion in the Global Crisis: The Case of the Southeastern Europe (SEE-7) Countries, "Journal of Economic and Social Studies", Vol 2, No. 2.

Trichet J.C., 2000, Introductory Remarks, [in:] Independence and Accountability Developments in Central Banking, Bank of France.

Wheelock D.C., Wilson P.W., 1999, Technical progress, inefficiency and productivity change in US banking, 1984-1993. "Journal of Money, Credit, and Banking", No. 31. https://doi.org/ $10.2307 / 2601230$. 
Wilkin J., 1991, Jaki kapitalizm, jaka Polska?, Zbyt powolna zmiana systemu, „Gospodarka Narodowa", nr 3.

Wojtyna A., 1997, Strategia gospodarcza a ekonomia polityczna reform, [in:] Dynamika transformacji polskiej gospodarki, M. Belka, W. Trzeciakowski (red.), INE PAN, Warszawa. 
